\title{
El museo virtual llega al campus: Dos perspectivas del proyecto de licencia de acceso de las instituciones educativas a los museos (MESL)
}

\author{
Angela Giral \\ Biblioteca Avery \\ Universidad de Columbia. Nueva York \\ Jeannette Dixon \\ Biblioteca Hirsch \\ Museo de Bellas Artes. Houston. Texas
}

EI Programa de Información de Historia del Arte (AHIP) de la Fundación Getty, se ha unido a la MUSE Educational Media en un proyecto en el que participarán siete universidades y siete museos de arte con el fin de facilitar imágenes digitales de obras de arte a estudiantes y profesores a través de las redes de los campus. Más allá de los beneficios inmediatos para los participantes, el proyecto se ha diseñado para desarrollar métodos y directrices para el uso académico del material digitalizado de los objetos pertenecientes a los museos en las universidades. La Universidad de Columbia y el Museo de Bellas Artes de Houston son dos de los participantes del proyecto, del que hay que destacar el notable nivel de colaboración alcanzado entre museos y universidades.

\section{El proyecto}

Desde sus comienzos en 1983, el Programa de Información de Historia del Arte (AHIP) de la Fundación Getty ha pretendido que la información sobre historia del arte sea más accesible a través de la tecnología electrónica. Las imágenes digitales ofrecen el potencial para que nuestro patrimonio cultural esté disponible a una mayor audiencia, de manera nunca antes pensada. La distribución de estas imágenes a través de las redes de comunicación está cambiando la naturaleza de la enseñanza y de la investigación. Pero, para que esta transformación sea completa, debe existir un importante volumen de información digital, que debe estar disponible de forma normalizada. Los sistemas de imágenes requieren también un equilibrio complejo entre los intereses de los propietarios de los derechos y los deseos de aquéllos que utilizan las imágenes para su estudio, investigación, o entretenimiento. Sin un marco común de derechos, permisos y restricciones, el desarrollo de los sistemas de imágenes se verá obstaculizado.
El MESL reúne a importantes museos y universidades para definir los términos y las condiciones de uso de las imágenes y la información de los museos en las redes de los campus con fines educativos. Esta iniciativa de colaboración, de dos años de duración, desarrollará métodos y directrices para el uso académico en las universidades del material digitalizado de los objetos pertenecientes a los museos. Las instituciones educativas y los museos seleccionados colaborarán de buena fe para llegar a un acuerdo sobre los términos de captura, distribución, y utilización de las imágenes de las obras que se incluyen de las distintas colecciones de los museos y de los textos relativos a éstas. El proyecto se realiza con el interés de explorar y promocionar los beneficios educativos del acceso digital a las colecciones de los museos, a través de las redes informáticas de los campus.

Los museos facilitarán imágenes e información. Las instituciones educativas facilitarán el acceso a las imágenes a través de las redes y la utilización de éstas con fines educativos. Entre todos los participantes del proyecto se definirán los términos y las condiciones que regirán la futura distribución y utilización académica de las imágenes y de la información de los museos en los campus universitarios.

Los museos participantes son: Museo Fowler de Historia Cultural en la Universidad de California, Los Ángeles; The George Eastman House, Rochester; Museos de Arte de la Universidad de Harvard en Cambridge, Massachusetts; la Biblioteca del Congreso; Museo de Bellas Artes de Houston; la Galería Nacional de Arte de Washington D.C.; y el Museo Nacional de Arte Americano, Washington D.C. las universidades participantes son: la Universidad Americana de Washington D.C.; la Universidad de Columbia, Nueva York, Nueva York; la Universidad de Cornell, Ithaca, Nueva York; la Universidad de Illinois en Urbana-Champaign; la Universidad de Maryland en College Park; Universidad de Michigan; y la Universidad de Virginia. Cada institución participante presentará un equipo interdisciplinar de expertos en las materias de historia del arte, documentación de colecciones de museos, e informática en el campo académico y en el de las imágenes. Además, una red de observadores, formada entre los más de 80 museos y universidades que solicitaron participar en el proyecto, junto a otras partes interesadas, permitirá al resto de la comunidad seguir el desarrollo del proyecto. 
Los museos participantes pondrán a disposición de las instituciones educativas imágenes digitalizadas e información de al menos 6.000 obras ( 1.000 de cada museo en cada uno de los dos años) en formatos normalizados. Las instituciones educativas instalarán estas imágenes digitalizadas, y los textos descriptivos que las acompañan, en las redes informáticas de los campus para su investigación y estudio durante los cursos académicos 1995-1996 y 1996-1997. Los museos seleccionarán las obras que se incluirán en el proyecto en base a los criterios que las universidades sugieran. Las instituciones educativas propondrán y explorarán una amplia variedad de usos educativos y de investigación para el material.

Durante el proyecto, las imágenes y su documentación se proporcionarán sin licencias y sin tarifas. Esto permitirá a los participantes evaluar y comparar los distintos usos de las imágenes y de la información en los campus universitarios para definir requisitos de seguridad en las redes y evaluar varios métodos tecnológicos para su ejecución, y desarrollar los términos de un acuerdo modelo de licencia. Una vez finalice el período de prueba de dos años, se retirarán de las redes de los campus tanto las imágenes como la información, a no ser que se establezcan acuerdos de licencias que permitan la continuidad de su utilización.

Los museos, las galerías y las instituciones educativas participantes contribuirán a la ejecución del proyecto con el tiempo de su personal y con recursos técnicos. La Imaging Initiative, del Programa de Información de Historia del Arte de la Fundación Getty, se encarga de la planificación y de la organización, y también proporcionará algunos de los fondos necesarios para la ejecución del proyecto. El resto de los fondos se recogerá de fundaciones privadas y públicas. Su administración corre a cargo de una organización asociada a AHIP: la MUSE Educational Media, que es una organización no lucrativa cuyo Grupo de Estudio de Multimedia se dedica a desarrollar acuerdos modelo de licencia para el uso de imágenes de museos en publicaciones en CD-ROM. El proyecto cuenta con el apoyo de la Asociación Americana de Directores de Museos de Arte, con el de la Asociación Americana de Museos y con el de la Coalición para la Información en Red.

\section{La Universidad de Columbia}

La Universidad de Columbia, fundada en 1754 bajo el nombre de King's College mediante real decreto del rey Jorge II de Inglaterra, es la institución de educación superior más antigua del estado de Nueva York y la quinta más antigua de los Estados Unidos. El actual sistema de bibliotecas es descendiente directo de la biblioteca del King's College. Las colecciones de las bibliotecas de la Universidad de Columbia cuentan en estos momentos con más de 6,3 millones de volúmenes, y cada año se añaden más de 124.000. Además, las colecciones contienen más de 4,6 millones de microformas, 26 millones de manuscritos, y 35.000 títulos de publicaciones periódicas de serie. Las bibliotecas cuentan también con importantes colecciones de CD-ROM, archivos de datos, mapas, grabaciones de sonido y folletos. Los recursos se facilitan a través de 22 bibliotecas que se encuentran en el campus. Además de las colecciones locales, las bibliotecas facilitan el acceso electrónico a más de 50 bases de datos a través del servicio CLIO Plus. Las bibliotecas enriquecen diariamente sus recursos electrónicos a través de las ofertas de su Servicio Electrónico de Datos, de su Servicio Electrónico de Textos y de muchos menús de servicios especializados.

El Acls (Academic Information Systems/Sistemas de Información Académica), que cuenta con 45 miembros del personal profesional de FTE y 65 estudiantes, proporciona la infraestructura de cálculo y de red a la comunidad de Columbia. AcIS opera con un grupo central de terminales Unix, principalmente Sun Sparc 20, para proporcionar servicios generales de tiempo compartido y de correo electrónico a los más de 20.000 usuarios afiliados. Los servidores de información de la red admiten los servicios Gopher, World Wide Web y Z39.50 y facilitan un directorio de bases de datos y servicios de seguridad a los 60.000 miembros de la comunidad de Columbia en varios campus.

Desde todos los edificios del campus central se puede acceder a la red de Columbia, que que proporciona el acceso a Internet a todas las facultades y oficinas de administración, y desde septiembre de 1995, todas las residencias del campus disfrutan del mismo acceso a la red. En Columbia existen varios gabinetes de informática y aulas de electrónica que sirven de apoyo a la enseñanza. Las aulas de electrónica están equipadas con ordenadores y equipos de proyección, y en la mayoría se dispone de lectores de CD-ROM, reproductores de vídeo, lectores de discos láser, y sistemas audiovisuales. Estas aulas están conectadas a la red del campus.

AcIS dirige además uno de los primeros sistemas de información extendidos por todo el campus: ColumbiaNet (al que pertenece CLIO), que facilita el acceso a más de 9.000 servicios de información locales y remotos, al igual que proporciona puertas de acceso a sistemas de mayor amplitud como son el servicio Gopher y la WWW de Internet. ColumbiaNet ofrece acceso por red y/o conmutado, permite varias sesiones simultáneas y cumple varias restricciones de licencia utilizando software que se desarrolla localmente.

AcIS y las bibliotecas están trabajando en estos momentos en una iniciativa de biblioteca digital, por medio de la cual se están desarrollando de forma coordinada herramientas de acceso, sistemas de entrega y herramientas de apoyo a las colecciones. La iniciativa de la biblioteca digital ha desarrollado, y lo sigue haciendo, relaciones contractuales con varias editoriales comerciales y otras instituciones de educación superior, que están comenzando a proporcionar más recursos electrónicos a nuestra comunidad a través de la red del campus.

Las restricciones de acceso a los servicios de infraestructura de Columbia se llevan a cabo a través del sistema de seguridad "Kerberos" que funciona entre los clientes y cualquier servicio de la red ColumbiaNet, abarcando a unos 60.000 usuarios del Sistema de Infor- 
mación para el Personal (facultativos y administrativos), del Sistema de Información del Estudiante (estudiantes), y de las instituciones afiliadas. Las "cargas" diarias de estos sistemas de administración actualizan de forma automática la base de datos de Kerberos, proporcionando derechos de acceso e información demográfica de la totalidad de la comunidad. Las restricciones a servicios particulares derivan, por su parte, de la información demográfica.

El desarrollo de la biblioteca digital se centra en estos momentos en un grupo de proyectos piloto de entrega de textos completos y de imágenes estáticas. Además de la entrega por medio de la red, todos los proyectos se ocupan del diseño de interfaces de usuario, de la integración con otros servicios del campus y con la presentación general de la biblioteca digital, del acceso bibliográfico a todos los elementos de la red, y de la evaluación de los proyectos. Las bibliotecas han recibido una subvención de la Fundación Andrew W. Mellon para una evaluación en profundidad de todos los proyectos pilotos textuales que se están llevando a cabo en estos momentos, y las metodologías y los programas estadísticos que se desarrollen con este motivo se aplicarán al proyecto MESL.

El comité de imágenes (PixCom) de Columbia, se creó con motivo de la participación de Columbia en el Proyecto de Acceso a Imágenes Digitales (DIAP) de RLG, en el que Columbia fue una de las ocho instituciones que contribuyeron con aproximadamente 1.000 imágenes sobre el tema genérico de paisaje urbano. Las funciones del equipo se ampliaron después para desarrollar proyectos locales de imágenes más allá de las limitadas fronteras del DIAP, y fue este mismo equipo el que desarrolló la propuesta de participación en el proyecto MESL y quien estará a cargo de tal proyecto. El equipo está formado por el Delegado de Bibliotecas de la Universidad; el Director de la Biblioteca Avery de Arquitectura y Bellas Artes; el Director de Investigaciones y Desarrollo de AcIS, que además es el Coordinador de Desarrollo Técnico de la Biblioteca Digital; el Consejero Técnico de los Servicios para Usuarios de AcIS; el Director del Departamento de Conservación de las Bibliotecas; el Director del Departamento de Control y Tratamiento Bibliográfico de las Bibliotecas; el Director del Departamento de Sistemas Bibliotecarios; el Director del Instituto de Tecnologías de Aprendizaje; el Conservador de la Colección de Fotografías/Diapositivas del Departamento de Arqueología e Historia del Arte; y el Coordinador de los Proyectos de Imágenes de la Biblioteca Avery de Arquitectura y Bellas Artes. El Comité de Recursos Visuales de la Facultad del Departamento de Historia del Arte y Arqueología se establece como órgano consultivo para el equipo del proyecto.

El equipo encargado del proyecto ha estado trabajando en otros proyectos de imágenes y ha desarrollado una metodología para proporcionar tres niveles de acceso a través de la World Wide Web. El primero es el acceso a la colección permanente de imágenes a través de un grupo jerárquico de registros MARC creados en CLIO (catálogo de acceso en línea de Columbia) y conectados a la WMW a través de filtros diseñados por los miembros de AcIS, con capacidad para convertir los registros MARC en documentos HTML asociados a imágenes. El segundo nivel de acceso es para páginas "de reserva", para el que se ha diseñado un prototipo de página para cursos capaz de admitir imágenes de la colección permanente junto con imágenes "reservadas" para un curso específico y procedente de varias fuentes.. El tercer nivel está destinado a la creación de páginas de profesores (de las que ya existen un buen número) que pueden tener varias formas y utilizaciones dependiendo del estilo de enseñanza y de la competencia del profesor en cuestión.

\section{El Museo de Bellas Artes de Houston}

Los siete museos que antes señalamos fueron seleccionados para representar diferentes tipos de instituciones en diferentes puntos geográficos con diferentes tipos de colecciones. La tarea principal de los museos en este proyecto es proporcionar imágenes digitalizadas de objetos de sus colecciones permanentes, además del texto descriptivo de cada objeto. Los museos también proporcionan la experiencia del personal de varios departamentos en la realización del proyecto. En el Museo de Bellas Artes de Houston el equipo encargado del proyecto incluye varios jefes de departamento: el Director de Educación, que está a cargo de todos los programas dirigidos al público, toma las decisiones sobre qué imágenes se deben incluir en el proyecto y ayuda a diseñar las herramientas de evaluación; el Catalogador, que controla los registros de los objetos del museo, ayuda a seleccionar los campos para las descripciones normalizadas de los objetos y dirige la selección de las diapositivas que se han de digitalizar; y el Bibliotecario, que cubre las necesidades informativas de los visitantes del museo y del personal profesional, coordina el proyecto y pone al cargo de algunos miembros del personal diferentes tareas relacionadas con el proyecto. Estas personas, además del Administrador, el Director del Departamento de Subvenciones, el Conservador de Fotografías, y el Director de Publicaciones, forman el equipo encargado del proyecto, que coordinan el proyecto a través del correo electrónico.

A medida que la naturaleza de las publicaciones cambia del lento mundo de la publicación impresa al de las publicaciones electrónicas, los museos necesitan disponer de una forma de facilitar el acceso a sus imágenes sin perder el control sobre su utilización. También necesitan disponer de un método de cobrar tarifas por la utilización de las imágenes de sus obras de arte que sea estable y de fácil mantenimiento. Parte de este proyecto consiste en la creación de un acuerdo preliminar de licencia, que recogerá cuestiones como el uso correcto de las imágenes, el copyright y los honorarios de los museos. Los museos esperan además saber de qué manera los programas creados por la universidad pueden incluir imágenes de obras de arte con fines educativos, y cómo se pueden aplicar más tarde a sus propios proyectos para enseñar a los visitantes sobre sus obras de arte. Por ejemplo, los museos podrían diseñar terminales de consulta para que los visitantes accedan a la información que deseen. Los museos también esperan que si los profesores de las universidades 
y los estudiantes graduados tienen un mayor acceso a las imágenes de las obras incluidas en sus colecciones, se realizarán más trabajos de investigación, que luego se podrán incorporar a la documentación de los objetos, e incluir en las publicaciones destinadas al público.

Otro de los principales deseos de los museos es que se conozcan más sus colecciones. La mayoría de los museos sólo han publicado una parte de las obras que poseen. En el pasado, los estudiantes universitarios han tenido acceso limitado a estas imágenes y a veces no han podido acceder a ellas en absoluto. Se espera que con la exposición de las obras de arte en formato electrónico, los estudiantes visiten los museos más tarde para verlas en persona.

Existe otra forma en que los museos se pueden beneficiar de este proyecto, aunque es más hipotética: Este proyecto puede ampliarse de manera que incluya objetos de colecciones de museos de todo el mundo que se puedan reproducir para conferencias, publicaciones y otros fines educativos. Si existiera un gran banco de imágenes de colecciones de museos, las costosas e incompletas bibliotecas de diapositivas y las oficinas de derechos y reproducciones de los museos podrían cambiar radicalmente. Una solicitud de reproducción de una imagen podría tardar segundos en lugar de semanas. El control de facturas individuales quedaría eliminada y se establecería una fuente de ingresos estable para los museos.

\section{Metodología}

Los coordinadores del proyecto se reúnen dos veces al año para conocerse, planificar el proyecto y desarrollar un cronograma. Los equipos encargados del proyecto de cada una de las instituciones participantes, tienen acceso a la BBS electrónica de este proyecto a través de Internet. Los coordinadores y los participantes del proyecto han utilizado asiduamente el servicio de distribución de correo MESL-L. Las actas de la primera reunión, celebrada en Washington D.C. en febrero de 1995, se publicaron en la listserv de la MESL-L. Se han discutido muchas cuestiones, tanto técnicas como teóricas, entre las que podemos destacar: el objetivo del proyecto; explicaciones sobre el formato JPEG para digitalizar las imágenes; solicitudes para la inclusión de tipos de imágenes; distribución de cronogramas; recopilación de información financiera de instituciones para incluirlas en futuras solicitudes de subvenciones; etc. Además, algunos integrantes de los equipos del proyecto se ofrecieron voluntarios para formar parte de grupos de trabajo específicos encargados de: el control y la seguridad; la distribución; la documentación; la selección de contenidos; la WWW; la evaluación; los fondos; y la formación en las facultades.

Se han incluido imágenes en una página de pruebas de la WWW. La dirección es:

http://www.umcp.umd.edu/MESL/home.html.

Estas imágenes se escanearon con una resolución alta para que los usuarios puedan aumentar su tamaño tanto como deseen y así poder examinar detalles de las obras de arte.

Antes del I de junio de 1995 los museos han debido efectuar la primera entrega de 500 imágenes digitaliza- das a la central para que los profesores universitarios accedieran a ellas. Cada una de las universidades participantes declaró haber programado al menos un curso para otoño de 1995 en el que se utilizarían imágenes de la base de datos del proyecto en la red del campus.

\section{Conclusiones}

A pesar de que el modelo de este tipo de proyecto de colaboración existe desde hace 20 años en el entorno de las bibliotecas (p.e. proyectos en la Red de Información de las Bibliotecas de Investigación en los EE.UU.), este tipo de colaboración entre museos y universidades es nuevo. Y mientras el acceso a Internet es algo más bien común en todas las universidades, la mayoría de los museos está empezando ahora a sentir la necesidad de conectarse. Este proyecto establece un modelo de trabajo para que los museos y las universidades se unan con el fin de explorar el potencial del "museo virtual". En el pasado, los museos han funcionado más bien como castillos amurallados, donde los objetos se trataban como tesoros, en vez de considerarse sistemas de información. Este proyecto ya ha derribado algunos "muros" de miedo a la pérdida del control por parte de los museos, y ha provocado nuevas formas de pensar sobre la manera de conseguir nuevas audiencias, además de aumentar la base de conocimientos sobre las obras de arte, no sólo desde dentro del museo, sino también gracias a los estudiantes del exterior. El museo está construyendo un puente sobre el foso, y permitiendo que los usuarios finales "jueguen" con sus imágenes, "creen" exposiciones virtuales, y disfruten de las obras de arte cuando deseen y sin tener que desplazarse hasta el museo.

Por parte de las universidades, los departamentos de humanidades estaban rezagados en el uso de los medios electrónicos, y la disponibilidad de imágenes de gran calidad proporcionadas por los museos que poseen los originales otorga una gran oportunidad a los profesores de historia del arte y otras disciplinas humanísticas para introducirse en este espléndido nuevo mundo. Algunos han avanzado a grandes pasos: por ejemplo, en la universidad de Columbia, un historiador de arquitectura está utilizando imaginativamente los programas CAD (diseño asistido por ordenador) para explicar la construcción de las catedrales medievales (Proyecto Amiens). Pero otros solicitan más formación y asistencia tecnológica.

Creemos que ambos tipos de instituciones tienen mucho que aprender, juntos y los unos de los otros.

Traducción

Begoña González Bourrelier 